\title{
Comparison of total tract digestibility and nitrogen balance between Cinta Senese and Large White pigs fed on different levels of dietary crude protein
}

\author{
A. Acciaioli, F. Sirtori, L. Pianaccioli, G. Campodoni, C. Pugliese, R. Bozzi, O. Franci* \\ Department of Agricultural Biotechnology, Animal Science Section, Via delle Cascine 5, 50144 Firenze, Italy
}

\section{A R T I C L E I N F O}

\section{Article history:}

Received 19 November 2010

Received in revised form 24 May 2011

Accepted 25 May 2011

\section{Keywords:}

Cinta Senese

Local pig

Digestibility

Nitrogen balance

Dietary protein

\begin{abstract}
A B S T R A C T
The work aimed to study the digestive capacity and nitrogen balance of Cinta Senese pig fed diets with different crude protein (CP) content. Twelve castrated male pigs (6 Cinta Senese and 6 Large White), of the same body weight (on average $62.7 \mathrm{~kg}$ ), were submitted to 8 subsequent trials of total tract digestibility and nitrogen balance. The pigs were kept in metabolism cages allowing collection of faeces samples and total urine. The diets, of exclusive vegetal origin, were formulated to contain four protein levels $70,100,130$ and $160 \mathrm{~g} / \mathrm{kg}$ as fed (named CP7, CP10, CP13 and CP16, respectively) assured mainly by soybean meal. Total tract nutrient apparent digestibility did not differ $(\mathrm{P}>0.05)$ between breeds. Apparent digestibility of $\mathrm{CP}$ increased $(\mathrm{P}<0.01$ ) with increasing dietary $\mathrm{CP}$ (from 0.756 to 0.874 for Cinta Senese and from 0.742 to 0.868 for Large White), as consequence of faecal endogenous nitrogen which underestimates the digestibility of protein in inverse proportion with its amount in the diet. Nitrogen balance showed that breed differences $(\mathrm{P}<0.01)$ emerged for the urinary $\mathrm{N}$ and the total excreted $\mathrm{N}$, with higher emission in Cinta Senese than in Large White breed. The difference was not significant at CP7 diet (excreted N: 19.4 vs. $17.1 \mathrm{~g} / \mathrm{d}$ for Cinta Senese and Large White) but became progressively more important $(\mathrm{P}<0.01)$ in the diets with higher CP content (excreted N at CP16 diet: 39 vs. $35.4 \mathrm{~g} / \mathrm{d}$ for Cinta Senese and Large White). Consequently, Large White retained more nitrogen than Cinta Senese (about +2.6; +3.0; +3.4; +3.8 g/d with CP7; CP10; CP13; CP16 diet, respectively; $\mathrm{P}<0.01$ ). So, the efficiency of $\mathrm{N}$ utilization (retained $\mathrm{N} /$ absorbed $\mathrm{N}$ ), favoured the Large White in all the tested diets $(\mathrm{P}<0.01)$. These results suggest to limit the CP content in diets for Cinta Senese breed, to reduce nitrogen pollution in the environment.
\end{abstract}

(c) 2011 Elsevier B.V. All rights reserved.

\section{Introduction}

Most studies on protein requirements in pigs were conducted since long time in order to optimize growth rate and feed efficiency, to limit the costs and to reduce the nitrogen pollution in the environment. The researches were carried out on pigs belonging to improved breeds modulating the quantitative and qualitative content of dietary protein and aimed at verifying growth and carcass performances (Tuitoek et al., 1997; Chen et al., 1999; Kerr et al., 2003), at studying ileal digestibility

Abbreviations: ADF, acid detergent fibre; AIA, acid insoluble ash; CP, crude protein; CS, Cinta Senese; CTTAD, coefficient of total tract apparent digestibility; DCP, dietary crude protein; DM, dry matter; LW, Large White; NDF, neutral detergent fibre; PDO, protected designation origin; TTAD, total tract apparent digestibility.

* Corresponding author. Tel.: +39 055 3288263; fax: +39 055321216 .

E-mail address: oreste.franci@unifi.it (O. Franci). 
Table 1

Experimental design and sequence of periods of adaptation to diet on floor and of digestibility trial on cage.

\begin{tabular}{|c|c|c|c|c|}
\hline \multirow[t]{2}{*}{ Week of trial } & \multicolumn{2}{|l|}{ Cinta Senese } & \multicolumn{2}{|l|}{ Large White } \\
\hline & Group 1 (pigs 1-3) & Group 2 (pigs 4-6) & Group 1 (pigs 7-9) & Group 2 (pigs $10-12$ ) \\
\hline 1 & Cage $C P 10^{a}$ & Floor CP16 & Cage $\mathrm{CP} 1^{\mathrm{a}}$ & Floor CP16 \\
\hline 2 & Floor CP7 & Cage CP16 & Floor CP7 & Cage CP16 \\
\hline 3 & Cage CP7 & Floor CP13 & Cage CP7 & Floor CP13 \\
\hline 4 & Floor CP13 & Cage CP13 & Floor CP13 & Cage CP13 \\
\hline 5 & Cage CP13 & Floor CP7 & Cage CP13 & Floor CP7 \\
\hline 6 & Floor CP16 & Cage CP7 & Floor CP16 & Cage CP7 \\
\hline 7 & Cage CP16 & Floor CP10 & Cage CP16 & Floor CP10 \\
\hline 8 & & Cage CP10 & & Cage CP10 \\
\hline
\end{tabular}

In bold the periods of digestibility trial.

a Preceded by a 7-day period on floor for adaptation to diet.

of amino acids (Fan et al., 1994; Buraczewska et al., 1999; Fan and Sauer, 2002), at estimating total tract digestibility and nitrogen balance (Bosi et al., 1995; Lindberg and Andersson, 1998; Canh et al., 1998; Le Bellego et al., 2001; Deng et al., 2007).

The recovery and valorisation of the autochthonous Mediterranean pig breeds, with low potential for lean growth and high adipogenetic capacity (Lopez-Bote, 1998; Franci et al., 2001; Gandini et al., 2001), suggest the need of analogous studies dedicated to them. Actually, few information on the optimal content of dietary protein for local pigs are available. On Iberian pig, studies tested the protein requirement from 15 to $50 \mathrm{~kg}$ (Nieto et al., 2002) or from 50 to $100 \mathrm{~kg}$ of body weight (Barea et al., 2006) and indicated the optimal protein content of the diet should be 130 and $95 \mathrm{~g} / \mathrm{kg}$ of DM, until $50 \mathrm{~kg}$ and from 50 to $100 \mathrm{~kg}$ of body weight, respectively. On Cinta Senese, a local breed of Tuscany, Sirtori et al. (2010) reported that $100 \mathrm{~g} / \mathrm{kg}$ of dietary protein can be used beyond $70 \mathrm{~kg}$ of body weight. On the contrary, relevant studies on digestibility and nitrogen balance are scarce: for instance, Freire et al. (1998) studied the digestive capability of new weaned Alentejano piglets in comparison with Large White whereas Acciaioli et al. (2003) investigated the digestive utilization and nitrogen balance of field bean in Cinta Senese pig, however, no information on modulation of dietary protein content in local pigs are available.

This study aimed to quantify the digestive capacity and nitrogen utilization of Cinta Senese, the most widespread Italian local pig, in comparison with Large White breed, fed diets covering a wide range of protein content, from well in excess to marginal deficiency.

\section{Materials and methods}

\subsection{Animals, design and diets}

Twelve castrated male pigs [6 Cinta Senese (CS) and 6 Large White (LW)], of the same weight at the start of the experiment (overall mean 62.7; s.d. $6.1 \mathrm{~kg}$ ) and of different ages (CS 5 months; LW 4 months), were submitted to 8 subsequent trials of digestibility and nitrogen balance, using metabolism cages $(60 \mathrm{~cm} \times 130 \mathrm{~cm})$ to collect samples of faeces and total urine. Each cage period was preceded by a 7-day period on floor for adaptation to diet and lasted 7 days. Trial was composed of a phase of adaptation ( 3 days) and a phase of collection of faeces samples and of total urine (on 4 days) according to the methodology proposed by Schiavon et al. (1996) and in line with other total tract digestibility trials (Canh et al., 1998; Nieto et al., 2002). Two groups of three animals were set up for each breed and they were alternatively employed as shown in Table 1 . So, the six cages were contemporarily occupied by three subjects for each breed fed the same diet and each animal received all dietary treatments throughout the whole experiment. The average weights at entry in cage were not different between breeds and among diets $(\mathrm{P}>0.05)$. The entire experiment was conducted according to the guidelines on animal welfare in animal research of the Italian Legislative decree no. 116/1992.

The diets, of exclusive vegetal origin, were formulated to contain four protein levels: $70,100,130$ and $160 \mathrm{~g} / \mathrm{kg}$ as fed basis (named CP7, CP10, CP13 and CP16, respectively). Ingredients and chemical composition of the diets as fed are reported in Table 2, where it is evident that protein was assured mainly by soybean and no amino acid supplementation was made, according to the current feeding system of Cinta Senese, that often respects the rules of organic farming (European Commission, 2008) or of "Suino Cinto Toscano" PDO Consortium (INEQ 2007). Diets were pelleted to avoid single ingredients to be selected by the animals. Animals were fed twice daily. Daily feed allowance was $90 \mathrm{~g} / \mathrm{kg}$ of metabolic weight. Feed allowance was always completely ingested. Water was provided ad libitum. Metabolism cages were supplied with water nipple and trough and allowed to recover total urine in flasks added with $20 \mathrm{ml}$ of $8 \mathrm{~N}$ sulphuric acid, to avoid ammonia loss (Sardi et al., 1998). The daily urine production of each subject was weighed and sampled. Samples of faeces for each subject were collected thrice a day in order to create the individual daily faeces sample.

Urine was analysed for nitrogen content following Kjeldhal method. The analytical methods used for feed, faeces and urine are reported by Martillotti et al. (1987). Feed and faeces were submitted to proximate analysis and to acid insoluble ash (AIA) determination. Acid insoluble ash was used as undigestible internal marker in order to calculate the total tract apparent digestibility (TTAD) of dietary components following the method proposed by Van Keulen and Young (1977). 
Table 2

Ingredients and chemical composition of diets.

\begin{tabular}{|c|c|c|c|c|}
\hline & \multicolumn{4}{|l|}{$\operatorname{Diet}^{\mathrm{a}}$} \\
\hline & CP7 & CP10 & CP13 & CP16 \\
\hline \multicolumn{5}{|l|}{ Ingredients } \\
\hline Soybean meal & 120 & 190 & 260 & 340 \\
\hline Straw & 50 & 50 & 50 & 50 \\
\hline Sugar beet pulp & 120 & 110 & 90 & 60 \\
\hline Maize starch & 650 & 590 & 540 & 490 \\
\hline Calcium carbonate & 15 & 15 & 15 & 15 \\
\hline Dicalcium phosphate & 15 & 15 & 15 & 15 \\
\hline Sodium chloride & 4 & 4 & 4 & 4 \\
\hline Vitamin-mineral premix ${ }^{\mathrm{b}}$ & 10 & 10 & 10 & 10 \\
\hline Lignosulphite & 16 & 16 & 16 & 16 \\
\hline \multicolumn{5}{|l|}{ Composition (g/kg DM) } \\
\hline Dry matter & 858 & 875 & 877 & 878 \\
\hline Crude Protein & 83 & 110 & 153 & 183 \\
\hline Ether extract & 6 & 6 & 5 & 7 \\
\hline NDF & 118 & 123 & 122 & 117 \\
\hline ADF & 72 & 75 & 76 & 74 \\
\hline Ash & 77 & 80 & 72 & 83 \\
\hline Calcium & 10.6 & 10.7 & 10.8 & 10.8 \\
\hline Phosphorus & 4.3 & 4.8 & 5.3 & 5.8 \\
\hline Lysine $^{c}$ & 3.3 & 5.2 & 7.2 & 9.4 \\
\hline Methionine $e^{c}$ & 0.7 & 1.1 & 1.6 & 2.1 \\
\hline Gross energy $^{\mathrm{d}}(\mathrm{Mj} / \mathrm{kg} \mathrm{DM})$ & 16.89 & 17.09 & 17.30 & 17.50 \\
\hline
\end{tabular}

a $\mathrm{CP} 7, \mathrm{CP} 10, \mathrm{CP} 13, \mathrm{CP} 16=70,100,130,160 \mathrm{~g} / \mathrm{kg}$ of DCP, respectively.

b Vitamin-mineral premix provided per kg of feed: Vitamin A: 12,000 IU; Vitamin D3: 1800 IU; Vitamin E: 60 mg; Vitamin K: 2 mg; Vitamin B1: 1.5 mg; Vitamin B2: $4.0 \mathrm{mg}$; Vitamin B6: $4 \mathrm{mg}$; Vitamin B12: $0.020 \mathrm{mg}$; Calcium pantothenate: $15 \mathrm{mg}$; Folic acid: $0.5 \mathrm{mg}$; Biotin: $0.2 \mathrm{mg}$; Co: 0.80 Fe: $120 \mathrm{mg}$;: $0.8 \mathrm{mg}$; Mn: $60 \mathrm{mg}$; Cu: $20 \mathrm{mg}$; mg; Zn: $100 \mathrm{mg}$; Se: $0.15 \mathrm{mg}$.

c Calculated from tabulated data of the soybean meal alone (Antongiovanni and Gualtieri, 2002).

d Calculated from specific values of the analytical components.

\subsection{Statistical analysis}

Data were analysed by GLM Procedure (SAS, 2007) using the following model:

$$
Y_{i j k l}=\mu+B_{i}+S_{i j}+b_{i}^{*} P_{k}+c^{*} X_{i j k l}+E_{i j k l}
$$

where $Y=l$ th observation on $j$ th subject; $B=$ fixed effect of the $i$ th breed $(C S, L W)$; $S=$ fixed effect of the $j$ th subject within breed; $P=$ continuous effect of $k$ th protein content of diet; $X=$ continuous effect of body weight at trial start; $E=$ random error.

The actual CP content of the diets (DCP) was considered as continuous effect within each breed (intraclass regression). Results were reported as LS means along the regression line for each breed at the specific level of DCP (70, 100, 130 and $160 \mathrm{~g} / \mathrm{kg}$ ) and significance of linear regression was tested within each breed. The differences between the LS means of the breeds at each diet were statistically tested by Student's $t$-test.

\section{Results}

\subsection{Digestibility}

Table 3 reports individual feed and protein intakes and the coefficients of TTAD(CTTAD) for the major dietary components. Both dry matter and crude protein intakes did not differ $(P>0.05)$ between the breeds, since the feed administration was determined on the body weight basis. Also the CTTAD of the various dietary components were not different $(P>0.05)$ between the breeds for the various diets. As concerns the influence of DCP level on the TTAD, an evident effect was found only for CP whose digestibility increased with increasing DCP $(\mathrm{P}<0.01)$.

\subsection{Nitrogen balance}

Table 4 shows the results of nitrogen balance of the diets on the two breeds. Differences between breeds were found neither for $\mathrm{N}$ intake, nor for absorbed and faecal N. All these quantities, however, increased with the DCP content $(\mathrm{P}<0.01)$, despite the increase of the TTAD of $\mathrm{CP}$ (Table 3$)$. On the contrary, breed differences $(\mathrm{P}<0.01)$ emerged for the urinary $\mathrm{N}$ and, consequently, for the total excreted $\mathrm{N}$ with higher emission in Cinta Senese than in Large White breed. The efficiency of $\mathrm{N}$ utilization, expressed as apparent biological value (retained $\mathrm{N} /$ absorbed $\mathrm{N}$ ), was higher in the Large White for all diets $(\mathrm{P}<0.01)$, but it did not varied $(\mathrm{P}>0.05)$ with increasing DCP on both breeds. 
Table 3

Feed intake and total tract digestibilities in Cinta Senese (CS) and Large White (LW) pigs of the same body weight (62.7 kg) fed diets with increasing dietary crude protein content.

\begin{tabular}{|c|c|c|c|c|c|c|c|c|}
\hline & \multirow[t]{2}{*}{ Breed } & \multicolumn{4}{|l|}{ Diet $^{\mathrm{a}}$} & \multirow[t]{2}{*}{ Linear regression on $\mathrm{DCP}(\mathrm{P})$} & \multirow[t]{2}{*}{ Breed effect $(\mathrm{P})$} & \multirow[t]{2}{*}{ r.s.d. ${ }^{b}$} \\
\hline & & CP7 & CP10 & CP13 & CP16 & & & \\
\hline \multicolumn{9}{|l|}{ Intake $(\mathrm{g} / \mathrm{d})$} \\
\hline \multirow{2}{*}{ Dry matter } & $\mathrm{CS}$ & 1728 & 1737 & 1745 & 1754 & 0.06 & 0.82 & 23.43 \\
\hline & LW & 1724 & 1736 & 1749 & 1761 & $<0.01$ & & \\
\hline \multirow[t]{2}{*}{ Crude protein } & $\mathrm{CS}$ & 141 & 201 & 260 & 320 & $<0.01$ & 0.73 & 10.40 \\
\hline & LW & 142 & 202 & 261 & 321 & $<0.01$ & & \\
\hline \multicolumn{9}{|c|}{ Digestibility coefficient } \\
\hline \multirow[t]{2}{*}{ Dry matter } & CS & 0.869 & 0.867 & 0.866 & 0.864 & 0.52 & 0.98 & 0.012 \\
\hline & LW & 0.874 & 0.869 & 0.864 & 0.859 & 0.03 & & \\
\hline \multirow[t]{2}{*}{ Organic matter } & $\mathrm{CS}$ & 0.902 & 0.901 & 0.900 & 0.900 & 0.59 & 0.83 & 0.01 \\
\hline & LW & 0.905 & 0.901 & 0.898 & 0.894 & 0.05 & & \\
\hline \multirow[t]{2}{*}{ Crude protein } & $\mathrm{CS}$ & 0.756 & 0.789 & 0.832 & 0.874 & $<0.01$ & 0.58 & 0.033 \\
\hline & LW & 0.742 & 0.784 & 0.826 & 0.868 & $<0.01$ & & \\
\hline
\end{tabular}

a CP7, CP10, CP13, CP16 =70,100,130, $160 \mathrm{~g} / \mathrm{kg}$ of DCP, respectively.

b Residual standard deviation.

Table 4

Intake, balance and efficiency of utilization of nitrogen of the diets in Cinta Senese (CS) and Large White (LW) pigs of the same body weight (62.7 kg) fed diets with increasing dietary crude protein content.

\begin{tabular}{|c|c|c|c|c|c|c|c|c|}
\hline & \multirow[t]{2}{*}{ Breed } & \multicolumn{4}{|l|}{ Diet $^{\mathrm{a}}$} & \multirow[t]{2}{*}{ Linear regression on $\mathrm{DCP}(\mathrm{P})$} & \multirow[t]{2}{*}{ Breed effect $(P)$} & \multirow[t]{2}{*}{ r.s.d. ${ }^{\mathrm{b}}$} \\
\hline & & CP7 & CP10 & CP13 & CP16 & & & \\
\hline \multirow[t]{2}{*}{$\mathrm{N}$ intake $\mathrm{g} / \mathrm{d}$} & CS & 22.6 & 32.2 & 41.8 & 51.3 & $<0.01$ & \multirow[t]{2}{*}{0.68} & \multirow[t]{2}{*}{1.7} \\
\hline & LW & 22.9 & 32.4 & 41.9 & 51.5 & $<0.01$ & & \\
\hline \multirow[t]{2}{*}{ Absorbed N g/d } & CS & 16.6 & 25.9 & 35.2 & 44.5 & $<0.01$ & \multirow[t]{2}{*}{0.94} & \multirow[t]{2}{*}{2.2} \\
\hline & LW & 17.1 & 26.1 & 35.1 & 44.1 & $<0.01$ & & \\
\hline \multirow[t]{2}{*}{ Faecal N g/d } & CS & 6.0 & 6.3 & 6.6 & 6.8 & 0.10 & \multirow[t]{2}{*}{0.53} & \multirow[t]{2}{*}{0.9} \\
\hline & LW & 5.9 & 6.3 & 6.8 & 7.3 & $<0.01$ & & \\
\hline \multirow[t]{2}{*}{ Urinary $\mathrm{N}$ g/d } & CS & 13.4 & $19.6^{\mathrm{f}}$ & $25.9^{f}$ & $32.2^{\mathrm{f}}$ & $<0.01$ & \multirow[t]{2}{*}{$<0.01$} & \multirow[t]{2}{*}{2.7} \\
\hline & LW & 11.3 & $16.9^{g}$ & $22.4^{\mathrm{g}}$ & $28.0^{\mathrm{g}}$ & $<0.01$ & & \\
\hline \multirow[t]{2}{*}{ Total excreted N g/d } & CS & 19.4 & $25.9^{f}$ & $32.5^{f}$ & $39.0^{\mathrm{f}}$ & $<0.01$ & \multirow[t]{2}{*}{$<0.01$} & \multirow[t]{2}{*}{2.8} \\
\hline & LW & 17.1 & $23.2^{\mathrm{g}}$ & $29.3^{g}$ & $35.4^{\mathrm{g}}$ & $<0.01$ & & \\
\hline \multirow[t]{2}{*}{ Retained N g/d } & $\mathrm{CS}$ & 3.2 & $6.3^{f}$ & $9.3^{\mathrm{f}}$ & $12.3^{\mathrm{f}}$ & $<0.01$ & \multirow[t]{2}{*}{$<0.01$} & \multirow[t]{2}{*}{2.9} \\
\hline & LW & 5.8 & $9.2^{\mathrm{g}}$ & $12.7^{\mathrm{g}}$ & $16.1^{\mathrm{g}}$ & $<0.01$ & & \\
\hline \multirow[t]{2}{*}{$\mathrm{ABV}^{\mathrm{c}} \%$} & $\mathrm{CS}$ & $20.87^{d}$ & $23.29^{f}$ & $25.71^{f}$ & $28.12^{\mathrm{d}}$ & 0.12 & \multirow[t]{2}{*}{$<0.01$} & \multirow[t]{2}{*}{7.77} \\
\hline & LW & $30.21^{\mathrm{e}}$ & $32.46^{g}$ & $34.70^{g}$ & $36.94^{\mathrm{e}}$ & 0.14 & & \\
\hline
\end{tabular}

a CP7, CP10, CP13, CP16 = 70, 100,130, $160 \mathrm{~g} / \mathrm{kg}$ of DCP, respectively.

b Residual standard deviation.

c Apparent biological value = retained N/absorbed $\mathrm{N}$.

$\mathrm{d}, \mathrm{e}$ Between breeds and within diet, means with different letters differ $(\mathrm{P}<0.05)$.

f,g Between breeds and within diet, means with different letters differ $(\mathrm{P}<0.01)$.

\section{Discussion}

The common belief that the "rustic" pig could have higher digestive capability than the improved one is not proved in the present work and rarely confirmed in the available literature. The present results indicate that Cinta Senese and Large White breeds exhibited the same apparent digestive capability for all the dietary components and for all the tested diets. Different results were found in a previous work (Acciaioli et al., 2003) which showed that Cinta Senese pig had lower digestive capability than Large White. This discrepancy can be due to the fact that in the latter trial pigs of the two breeds were coetaneous, while in the present one they had the same weight and consequently Cinta Senese pigs, being older than Large White, could have improved their digestive ability. As concerns other local pigs, Freire et al. (1998) found that new weaned piglets of Alentejano breed had higher TTAD for some dietary components (fat and acid detergent fibre) than Large White ones but the wide difference in age with the subjects of the present study does not allow to draw a comparison. On the other hand, Morales et al. (2002), on barrows of $88 \mathrm{~kg}$ of body weight, found higher apparent digestibility for organic matter in Landrace than in Iberian breed whereas no difference was found for crude protein.

The result of the positive effect of DCP content on the apparent digestibility of CP is in agreement with the literature and can be considered spurious since the faecal endogenous nitrogen, practically constant, affects proportionally more the faeces with lower protein content. Various experiments documented this positive correlation, both at ileal and total tract level (Furuya and Kaji, 1989; Fan et al., 1994; Bosi et al., 1995; Canh et al., 1998; Le Bellego et al., 2001; Deng et al., 2007), but only Fan et al. (1994) clearly justified the result as influenced by endogenous CP.

Differences between the two breeds were evident for nitrogen balance, particularly as it concerns the urinary $\mathrm{N}$ emission that was higher in the local breed. Moreover, these losses were sensitive to the DCP content since the difference was 
not significant at the lowest DCP content and became progressively more important in the diets with higher CP content. Consequently, the Large White retained higher quantities of nitrogen than Cinta Senese $(\mathrm{about}+2.6 ;+3.0 ;+3.4 ;+3.8 \mathrm{~g} / \mathrm{d}$ at CP7, CP10, CP13 and CP16, respectively). However, there was a noticeable increase in $\mathrm{N}$ retention in both breeds as $\mathrm{N}$ intake increased, indicated by regression analysis which never deviated from linearity, even in Cinta Senese. The lower N utilization of Cinta Senese compared to Large White is in accordance with studies by Acciaioli et al. (2003) and studies by Freire et al. (1998) with Alentejano (another local breed) compared to modern genotype pig.

Generally, the progressive increase of N excretion as DCP increases is well documented in the literature on selected pigs (Canh et al., 1998; Le Bellego et al., 2001; Deng et al., 2007). These studies showed as well an increase of retained N but the trend appeared more attenuate, and sometimes not significant, than that of the present trial. However, it must be considered that the range of DCP content in those experiments was less wide and located more upward (from 123 to $189 \mathrm{~g} / \mathrm{kg}$ ) compared to the present study. Bosi et al. (1995) reported that urinary $\mathrm{N}$ in improved pig increased as dietary CP increased from 144 to 185 and subsequently to $225 \mathrm{~g} / \mathrm{kg}$, while retained $\mathrm{N}$ increased from 144 and $185 \mathrm{~g} / \mathrm{kg}$ and plateaued afterwards.

Cinta Senese breed was penalized in respect to Large White at all the DCP content also for the efficiency of N utilization (retained N/absorbed N). However, irrespective of the breeds, the values of the coefficients showed a not significant trend toward the DCP increase, in partial contrast with the findings of Canh et al. (1998) from 125 to $165 \mathrm{~g} / \mathrm{kg}$ DCP and Deng et al. (2007) from 136 to $182 \mathrm{~g} / \mathrm{kg}$ DCP, that found a decreasing trend.

\section{Conclusions}

Cinta Senese, the most widespread Italian local pig, has been compared with the Large White, the most known selected breed, for the digestive capacity and nitrogen utilization using diets covering a wide range of protein content, from well in excess to marginal deficiency. The digestive capacity of the local breed did not differ from the counterpart at the various protein contents of the diet. On the contrary, differences between the breeds emerged in the nitrogen utilization for which Cinta Senese was penalized more and more as dietary protein content increased. These results suggest to limit the DCP content for the local breed, also with the aim to reduce nitrogen pollution in the environment.

\section{Acknowledgements}

This study was supported by grant of ARSIA (Tuscany Region). The authors thank Mr. Silvano Lancini for technical assistance and "Ente Cassa di Risparmio di Firenze" for financial support for SAS licence.

\section{References}

Acciaioli, A., Pianaccioli, L., Campodoni, G., Bozzi, R., Pugliese, C., Franci, O., 2003. Apparent digestibility and nitrogen balance in Cinta Senese pig, utilization of field bean (Vicia faba L.). Ital. J. Anim. Sci. 2, 107-114.

Antongiovanni, M., Gualtieri, M., 2002. Nutrizione e alimentazione animale. Edizioni Edagricole, Bologna.

Barea, R., Nieto, R., Lara, L., Garcia, M.A., Vilchez, M.A., Aguilera, J.F., 2006. Effect of dietary protein content and feeding level on carcass characteristics and organ weights of Iberian pigs growing between 50 and $100 \mathrm{~kg}$ live weight. Anim. Sci. 82, 405-413.

Bosi, P., De Grossi, A., Macchioni, P., Casini, L., 1995. Dietary protein levels for maximum nitrogen retention in improved pigs reared up to 170 kg live weight. Zoot. Nutr. Anim. 21, 47-55.

Buraczewska, L., Wasilewko, J., Fandrejewski, H., Zebrowska, T., Han, I.K., 1999. Formulation of pig diets according to ileal digestible amino acid content. Livest. Prod. Sci. 59, 13-24.

Canh, T.T., Aarnink, A.J.A., Schutte, J.B., Sutton, A., Langhout, D.J., Verstegen, M.W.A., 1998. Dietary protein affects nitrogen excretion and ammonia emission from slurry of growing-finishing pigs. Livest. Prod. Sci. 56, 181-191.

Chen, H.Y., Lewis, A.J., Miller, P.S., Yen, J.T., 1999. The effect of excess protein on growth performance and protein metabolism of finishing barrows and gilts. J. Anim. Sci. 77, 3238-3247.

Deng, D., Huang, R.L., Li, T.J., Wu, G.Y., Xie, M.Y., Tang, Z.R., Kang, P., Zhang, Y.M., Fan, M.Z., Kong, X.F., Ruan, Z., Xiong, H., Deng, Z.Y., Yin, Y.-L., 2007. Nitrogen balance in barrows fed low-protein diets supplemented with essential amino acids. Livest. Sci. 109, $220-223$.

European Commission, 2008. Commission Regulation (EC) No 889/2008 of 5 September 2008 laying down detailed rules for the implementation of Council Regulation (EC) No 834/2007 on organic production and labelling of organic products with regard to organic production, labelling and control. Official Journal of the European Union, L 250, 18.9.2008, pp. 1-84.

Fan, M.Z., Sauer, W.C., 2002. Determination of true ileal amino acid digestibility and the endogenous amino acid outputs with barley samples for growingfinishing pigs by the regression analysis technique. J. Anim. Sci. 80, 1593-1605.

Fan, M.Z., Sauer, W.C., Hardin, R.T., Lien, K.A., 1994. Determination of apparent ileal amino acid digestibility in pigs, effect of dietary amino acid level. J. Anim. Sci. 72, 2851-2859.

Franci, O., Gandini, G., Madonia, G., Pugliese, C., Chiofalo, V., Bozzi, R., Acciaioli, A., Campodoni, G., Pizzi, F., 2001. Performances of Italian local breeds. Pig genetic resources in Europe. EAAP Publication N. 104, Wageningen Agricultural University ed., Wageningen, The Netherlands, pp. 67-76.

Freire, J.P.B., Peiniau, J., Cunha, L.F., Almeida, J.A.A., Aumatre, A., 1998. Comparative effects of dietary fat and fibre in alentejano and large white piglets. Digestibility, digestive enzymes and metabolic data. Livest. Prod. Sci. 53, 37-47.

Furuya, S., Kaji, Y., 1989. Estimation of the true ileal digestibility of amino acids and nitrogen from their apparent values for growing pigs. Anim. Feed Sci. Technol. 26, 271-285.

Gandini, G., Fortina, F., Franci, O., Madonia, G., Matassino, D., 2001. Pig genetic resources of Italy. Pig genetic resources in Europe. EAAP Publication N. 104 Wageningen Agricultural University ed., Wageningen, The Netherlands, pp. 33-40.

INEQ 2007. Suino Cinto Toscano DOP, protezione nazionale transitoria - D.M. 29/09/2006. Handbook n. 1 (formalities and procedures of the stakeholders to the control system). North East Quality Institute, San Daniele del Friuli, Italy.

Kerr, B.J., Southern, L.L., Bidner, T.D., Friesen, K.G., Easter, R.A., 2003. Influence of dietary protein level, amino acid supplementation, and dietary energy levels on growing-finishing pig performance and carcass composition. J. Anim. Sci. 81, 3075-3087.

Le Bellego, L., Van Milgen, J., Dubois, S., Noblet, J., 2001. Energy utilization of low-protein diets in growing pigs. J. Anim. Sci. 79, $1259-1271$. 
Lindberg, J.E., Andersson, C., 1998. The nutritive value of barley- based diets with forage meal inclusion for growing pigs based on total tract digestibility and nitrogen utilization. Livest. Prod. Sci. 56, 43-52.

Lopez-Bote, C.J., 1998. Sustained utilization of the Iberian pig breed. Meat Sci. 49 (suppl. 1), S17-S27.

Martillotti, F., Antongiovanni, M., Rizzi, L., Santi, E., Bittante, G., 1987. Metodi di analisi per la valutazione degli alimenti di impiego zootecnico. Quaderni metodologici no 8. IPRA-CNR, Roma.

Morales, J., Pérez, J.F., Baucells, M.D., Mourot, J., Gasa, J., 2002. Comparative digestibility and lipogenic activity in Landrace and Iberian finishing pigs fed ad libitum corn- and corn-sorghum-acorn-based diets. Livest. Prod. Sci. 77, 195-205.

Nieto, R., Rivera, M., Garcia, M.A., Aguilera, J.F., 2002. Amino acid availability and energy value of acorn in the Iberian pig. Livest. Prod. Sci. 77, 227-239.

Sardi, L., Martelli, G., Parisini, P., Scipioni, R., 1998. Influenza del metodo di raccolta e di conservazione degli excreta sul bilancio azotato del suino. Zoot. Nutr. Alim. 24, 163-170.

SAS, 2007. SAS/STAT User's guide. 9.1 version. SAS Institute Inc., Cary, NC, USA.

Schiavon, S., Ramanzin, M., Bittante, G., Bailoni, L., Gallo, L., 1996. Valutazione della digeribilità nei suini, confronto fra raccolta totale e sesquiossido di cromo con diete e periodi di campionamento diversi. Zoot. Nutr. Anim. 22, 23-32.

Sirtori, F., Acciaioli, A., Pugliese, C., Bozzi, R., Campodoni, G., Franci, O., 2010. Effect of dietary protein level (as substitution of maize with soybean meal) on growth rate and feed efficiency of Cinta Senese pig in the growing-fattening period. Ital. J. Anim. Sci. 9, 157-162.

Tuitoek, K., Young, L.G., de Lange, C.F.M., Kerr, B.J., 1997. Body composition and protein and fat accretion in various body components in growing gilts fed diets with different protein levels but estimated to contain similar levels of ideal protein. J. Anim. Sci. 75, 1584-1590.

Van Keulen, J., Young, B.A., 1977. Evaluation of acid-insoluble ash as a natural marker in ruminant digestibility studies. J. Anim. Sci. $44,282-287$. 